(c) American Dairy Science Association, 2006.

\title{
Feeding a Low Manganese Diet to Heifers During Gestation Impairs Fetal Growth and Development
}

\author{
S. L. Hansen, J. W. Spears, ${ }^{1}$ K. E. Lloyd, and C. S. Whisnant \\ Department of Animal Science, North Carolina State University, Raleigh 27695-7621
}

\begin{abstract}
A study was conducted to examine the effects of low dietary Mn on growth performance of pregnant heifers and fetal development of their offspring. Twenty pregnant Angus ( $=9)$ and Simmental $(\mathrm{n}=11)$ heifers averaging $17 \mathrm{mo}$ of age and $447.6 \mathrm{~kg}$ of initial body weight were used in the 267-d study. Heifers were selected from a previous study examining the effects of supplemental $\mathrm{Mn}$ on growth and reproductive performance of heifers. Ten pregnant heifers per treatment from the control (analyzed at $15.8 \mathrm{mg}$ of $\mathrm{Mn} / \mathrm{kg}$ of $\mathrm{DM}$ ) and supplemental $\mathrm{Mn}(50 \mathrm{mg} / \mathrm{kg}$ of $\mathrm{DM})$ treatments were randomly selected at the conclusion of the previous study to continue on their respective dietary treatments through gestation and early lactation. Serum cholesterol for the 267-d period was not affected by treatment. Whole-blood Mn concentration of heifers on d 267 was not affected by treatment. Whole-blood Mn concentration at birth was lower in calves born to control heifers than in those born to supplemented heifers. Calves born to control heifers weighed less at birth than those born to heifers receiving supplemental Mn. Calves born to control heifers suffered from varying signs of Mn deficiency, including superior brachygnathism, unsteadiness, disproportionate dwarfism, and swollen joints. Results suggest that feeding gestating heifers a diet containing $16.6 \mathrm{mg}$ of $\mathrm{Mn} / \mathrm{kg}$ of $\mathrm{DM}$ is not adequate for proper fetal development. Supplementation of $50 \mathrm{mg}$ of $\mathrm{Mn} / \mathrm{kg}$ of $\mathrm{DM}$ to the control diet was sufficient to overcome any signs of Mn deficiency in calves.
\end{abstract}

Key words: fetal development, heifer, manganese, reproduction

\section{INTRODUCTION}

Previous work in cattle has shown that Mn is required for proper skeletal development of young animals and normal reproductive performance in adults

Received March 26, 2006.

Accepted May 11, 2006.

${ }^{1}$ Corresponding author: Jerry_Spears@ncsu.edu
(Bentley and Phillips, 1951; Rojas et al., 1965). Manganese deficiency in the gestating female is often difficult to diagnose, with no apparent visual signs in the female herself. However, insufficient amounts of $\mathrm{Mn}$ in the diet of a pregnant heifer may lead to a variety of $\mathrm{Mn}$ deficiency signs in her calf, including ataxia and skeletal malformation (McDowell, 1992).

As an essential trace element, Mn plays a crucial role in several enzymes in the body, such as glycosyltransferases (Leach and Harris, 1997). Glycosyltransferases are a group of enzymes that are involved in the metabolism of cartilage proteoglycans, affecting the biosynthesis of glycosaminoglycan and oligosaccharide side chains (Leach and Harris, 1997). The role of Mn in cartilage formation makes it essential to the formation of the epiphyseal growth plate, which directly affects longitudinal bone growth. Thus, the most frequently observed sign of Mn deficiency in young animals is skeletal malformation (Leach and Muenster, 1962).

Recently, the NRC (2001) for dairy cattle reduced Mn requirements for the gestating dairy cow. For example, whereas the $\mathrm{Mn}$ recommendation for a gestating dairy cow was previously $40 \mathrm{mg}$ of $\mathrm{Mn} / \mathrm{kg}$ of $\mathrm{DM}$, the new NRC (2001) recommends $17.8 \mathrm{mg}$ of $\mathrm{Mn} / \mathrm{kg}$ of $\mathrm{DM}$ for a dry dairy cow (BW $=650 \mathrm{~kg}$ ) on d 270 of gestation. The current dairy cattle (NRC, 2001) recommendation for $\mathrm{Mn}$ in gestating cows is similar to concentrations (16 to $17 \mathrm{mg}$ of $\mathrm{Mn} / \mathrm{kg}$ of $\mathrm{DM}$ ) in beef cow diets reported to result in Mn deficiency in their offspring (Rojas et al., 1965). The most recent beef cattle NRC (1996) recommends $40 \mathrm{mg}$ of $\mathrm{Mn} / \mathrm{kg}$ of $\mathrm{DM}$ for reproducing beef cattle. Recently, Weiss and Socha (2005) estimated, based on Mn intake and fecal excretion, that dry and lactating dairy cows, respectively, require approximately 2.7 and 1.6 times more $\mathrm{Mn}$ for their maintenance requirements than values calculated using the current dairy cattle NRC model. The present study was designed to observe the effects of long term low-Mn diets on gestating heifers and their offspring.

\section{MATERIALS AND METHODS}

\section{Animal and Experimental Design}

Experimental procedures were reviewed and approved by the North Carolina State University Animal 
Care and Use Committee. Twenty pregnant Angus ( $\mathrm{n}=$ $9)$ and Simmental $(\mathrm{n}=11)$ heifers $(447.6 \mathrm{~kg}$ of initial BW) approximately $17 \mathrm{mo}$ of age were used in a $267-\mathrm{d}$ study examining the effects of long term feeding of a low-Mn diet on the offspring of heifers. Heifers were selected from a previous 196-d study examining the effects of varying levels of dietary $\mathrm{Mn}$ on growth and reproductive performance of heifers (Hansen et al., 2006). Heifers began on that study at approximately 10 mo of age (248.6 kg of initial BW) and were fed 0 (control), 10, 30, or $50 \mathrm{mg}$ of supplemental $\mathrm{Mn} / \mathrm{kg}$ of $\mathrm{DM}$ in addition to the basal diet (analyzed at $15.8 \mathrm{mg}$ of $\mathrm{Mn} / \mathrm{kg}$ of DM). Supplemental Mn was supplied from $\mathrm{MnSO}_{4}$. Heifers were synchronized for estrus and artificial inseminated at approximately $13 \mathrm{mo}$ of age.

Following rectal palpation for determination of pregnancy, 10 pregnant heifers per treatment were randomly selected from the control and $50 \mathrm{mg}$ of supplemental Mn/kg of DM treatments. Heifers continued on their previous dietary treatments, and were sorted by treatment and weight into pens, with 2 heifers in each pen, with mixed breeds. Pregnant heifers were housed in a covered facility with slotted floors that connected to gravel runs, and were bunk-fed by pen. Ingredient and chemical composition of the diets fed to heifers through the previous and current study are shown in Table 1. Diets were formulated to meet or exceed all NRC (1996) requirements for beef heifers with the exception of Mn. The control diet averaged $16.6 \mathrm{mg}$ of $\mathrm{Mn} /$ $\mathrm{kg}$ of DM for the growing phase, pregnancy, and early lactation. Heifers were fed once daily at a rate of $1.4 \%$ of BW until calving, after which feed amounts were increased to $1.8 \%$ of $\mathrm{BW}$ to accommodate lactation requirements. Weights were taken on d $0,28,54,84,112$, 140,170 , and 267 of the study. Jugular blood samples were taken on $d 0,54,112$, and 160 of the study for analysis of serum cholesterol concentration. Weights and blood samples were not taken during the period between calving and d 267. Heifers calved from d 179 to 226 of the study and calf birth weights and any signs of Mn deficiency were noted. A jugular blood sample for analysis of whole-blood Mn concentration was taken from calves within $24 \mathrm{~h}$ of birth and from both heifers and calves at the termination of the study (d 267), when calves averaged $67 \mathrm{~d}$ of age.

Visual signs of Mn deficiency were subjectively measured by an individual blind to treatment. Calves were classified as disproportionately dwarf if they were $\geq 5.08$ $\mathrm{cm}$ shorter than an aged-matched counterpart on the supplemented treatment based on hip height measurements taken on $d 267$ of the study. Calves were determined to be unsteady or weak if they were easily put off balance with a single hand push, and shook or trembled when walking, based on testing within a few days of
Table 1. Ingredient and chemical composition of diets fed to beef heifers from the growing phase through early lactation ${ }^{1}$

\begin{tabular}{|c|c|c|c|}
\hline & $\begin{array}{l}\text { Growing } \\
\text { and early } \\
\text { gestation }\end{array}$ & $\begin{array}{l}\text { Mid- } \\
\text { gestation }\end{array}$ & $\begin{array}{l}\text { Late } \\
\text { gestation } \\
\text { and early } \\
\text { lactation }\end{array}$ \\
\hline \multicolumn{4}{|l|}{ Ingredient, $\%$ of $\mathrm{DM}$} \\
\hline Cottonseed hulls & 40.0 & 40.0 & 40.0 \\
\hline Citrus pulp & 20.0 & 20.0 & 15.0 \\
\hline Corn gluten feed & 25.0 & 5.0 & 10.0 \\
\hline Ground corn & 11.71 & 31.71 & 31.96 \\
\hline Urea & 0.75 & 0.75 & 0.5 \\
\hline Calcium carbonate & 0.5 & 0.5 & - \\
\hline Dicalcium phosphate & - & - & 0.5 \\
\hline Vitamin premix ${ }^{2}$ & 0.03 & 0.03 & 0.03 \\
\hline Mineral premix ${ }^{3}$ & 0.01 & 0.01 & 0.01 \\
\hline Corn supplement ${ }^{4}$ & 2.0 & 2.0 & 2.0 \\
\hline \multicolumn{4}{|l|}{ Chemical composition } \\
\hline $\mathrm{CP}, \%$ of $\mathrm{DM}^{5}$ & 12.38 & 9.39 & 9.76 \\
\hline $\mathrm{NDF}, \%$ of $\mathrm{DM}^{5}$ & 50.88 & 45.44 & 46.13 \\
\hline ME, Mcal $/ \mathrm{kg}$ of $\mathrm{DM}^{5}$ & 2.40 & 2.46 & 2.47 \\
\hline $\mathrm{Mn}, \mathrm{mg} / \mathrm{kg}$ of $\mathrm{DM}^{6}$ & 15.8 & 18.6 & 16.3 \\
\hline
\end{tabular}

${ }^{1}$ Diet contained Rumensin (Elanco Animal Health, Indianapolis, IN) at $33 \mathrm{mg} / \mathrm{kg}$.

${ }^{2}$ Provided per kilogram of diet: 1,980 IU of vitamin A; 456 IU of vitamin $\mathrm{D}_{3}$; and $1.98 \mathrm{IU}$ of vitamin $\mathrm{E}$.

${ }^{3}$ Provided per kilogram of diet: $30 \mathrm{mg}$ of $\mathrm{Zn}$ as $\mathrm{ZnSO}_{4} ; 10 \mathrm{mg}$ of $\mathrm{Cu}$ as $\mathrm{CuSO}_{4} ; 0.5 \mathrm{mg}$ of $\mathrm{I}$ as $\mathrm{Ca}\left(\mathrm{IO}_{3}\right)_{2}\left(\mathrm{H}_{2} \mathrm{O}\right) ; 0.2 \mathrm{mg}$ of $\mathrm{Se}$ as $\mathrm{Na}_{2} \mathrm{SeO}_{3}$; and $0.1 \mathrm{mg}$ of $\mathrm{Co}$ as $\mathrm{CoCO}_{3}$.

${ }^{4}$ Provided supplemental $\mathrm{Mn}$ as $\mathrm{MnSO}_{4}$.

${ }^{5}$ Calculated value (NRC, 1996).

${ }^{6}$ Analyzed value.

birth. Calves were classified as suffering from superior brachgnathism based on visual detection of the bottom lip extending out from the upper or exposure of the bottom row of teeth.

\section{Analytical Procedures}

Whole blood was collected in heparinized vacuum tubes designed for trace mineral analysis (Becton Dickenson, Rutherford, NJ), and wet-ashed prior to $\mathrm{Mn}$ analysis. The ashing procedure was a modification of procedures as described by Legleiter et al. (2005). Five milliliters of trace metal-grade nitric acid was added to $1 \mathrm{~mL}$ of whole blood in $30-\mathrm{mL}$ beakers and boiled off on a hot plate. Then, $1 \mathrm{~mL}$ of $30 \%$ reagent-grade hydrogen peroxide was added to the beaker and boiled off. Dried samples were reconstituted using $1 \mathrm{~mL}$ of $5 \%$ nitric acid. Flameless atomic absorption spectroscopy (GFA-6500, Shimadzu Scientific Instruments, Kyoto, Japan) was used to determine Mn content of whole blood.

Blood for serum cholesterol samples was collected in vacuum tubes and allowed to clot at room temperature for $1 \mathrm{~h}$. Samples were then centrifuged at $1,200 \times g$ for $20 \mathrm{~min}$ at $20^{\circ} \mathrm{C}$ and analyzed using a colorimetric endpoint assay kit (ThermoDMA, Arlington, TX). 
Feed samples were prepared for Mn analysis by wet ashing using microwave digestion (Mars 5, CEM Corp., Matthews, NC) as described by Gengelbach et al. (1994). The Mn content of feed samples was determined by flame atomic absorption spectroscopy (Shimadzu Scientific Instruments).

\section{Statistical Analysis}

Statistical analysis of data was performed by analyses of variance for a completely randomized design using the Mixed procedure of SAS (SAS Inst. Inc, Cary, $\mathrm{NC}$ ) and least squares means are reported. The model for whole-blood Mn included the fixed effects of treatment and time and the treatment $\times$ time interaction, and weight change in the heifers included the fixed effects of treatment, breed, and all related interactions, with date of calving and calf birth weight used as covariant. The same model was utilized for serum cholesterol data, with day of sampling as the repeated measure, and included all related interactions. A covariate analysis was performed on calf whole-blood Mn on d 267 of the study, with age serving as the covariate term. Pen means served as the experimental unit for all measures, with the exception of calf birth weight and observed deficiency signs where individual animal served as the experimental unit. The model for calf birth weight included the fixed effects of breed, treatment, sex, and all related interactions. Observed deficiency signs were analyzed using the Genmod procedure of SAS (SAS Inst. Inc.) and included the fixed effects of treatment, with breed and sex removed from the model after testing for significance and finding none. Interactions that were not significant $(P \geq 0.05)$ for the measurement of interest were removed from the models.

\section{RESULTS AND DISCUSSION}

Pregnant heifers began calving at approximately 23 mo of age, at which point they had been on their respective dietary treatments for an average of $375 \mathrm{~d}$. Two Simmental heifers from the control treatment, and 1 Angus and 1 Simmental heifer from the supplemented treatment were found to be open on d 168 and were removed from the study. One control heifer gave birth to a stillborn calf, and one calf born to a supplemented heifer died within $3 \mathrm{~d}$ of birth. One heifer receiving supplemental Mn delivered twins, one born alive and the other dead. Data from these heifers, their calves, and the surviving twin calf were not included in statistical analysis. In all, 7 calves born to control heifers and 6 born to supplemented heifers were included in statistical analysis.

In a previous study, the effects of dietary Mn on growth, reproductive performance, and Mn status of
Table 2. Effects of Mn supplementation on weight change during pregnancy and lactation of beef heifers

\begin{tabular}{|c|c|c|c|c|}
\hline \multirow[b]{2}{*}{ Weight change, $\mathrm{kg}^{1,2}$} & \multicolumn{2}{|c|}{$\begin{array}{l}\text { Supplemental Mn, } \\
\mathrm{mg} / \mathrm{kg}\end{array}$} & \multirow[b]{2}{*}{ SEM } & \multirow[b]{2}{*}{$P$} \\
\hline & 0 & 50 & & \\
\hline Overall (d 0 to 267 ) & +50 & +61 & 20.46 & 0.75 \\
\hline d 0 to 170 (precalving) & +98 & +108 & 6.81 & 0.40 \\
\hline d 170 to 267 (postcalving) & -49 & -47 & 18.36 & 0.97 \\
\hline
\end{tabular}

heifers were investigated (Hansen et al., 2006). The addition of $50 \mathrm{mg}$ of $\mathrm{Mn} / \mathrm{kg}$ of $\mathrm{DM}$ to that control diet (containing $15.8 \mathrm{mg}$ of $\mathrm{Mn} / \mathrm{kg}$ of $\mathrm{DM}$ ) did not affect performance characteristics of the heifers, but tended to improve reproductive performance. Few studies have examined the long-term effects of feeding low-Mn diets to heifers, and previous studies had limited animal numbers ( $\mathrm{n}=2$ or 3; Bentley and Phillips, 1951; Rojas et al., 1965). We hypothesized that although the control diet containing $15.8 \mathrm{mg}$ of $\mathrm{Mn} / \mathrm{kg}$ of $\mathrm{DM}$ was adequate for growth and development of heifers, it might not be sufficient for proper fetal development in the gestating heifer.

Manganese supplementation to the control diet in this study (16.6 $\mathrm{mg}$ of $\mathrm{Mn} / \mathrm{kg}$ of $\mathrm{DM}$ ) did not affect weight change in heifers during pregnancy or lactation (Table 2). Serum cholesterol of heifers was affected by time $(P<0.001)$ but not treatment (Table 3$)$. Similar findings have been reported in sheep, where no differences in serum cholesterol were seen among lambs fed diets containing 0.8 or $29.9 \mathrm{mg}$ of $\mathrm{Mn} / \mathrm{kg}$ of $\mathrm{DM}$ for 16 wk (Lassiter and Morton, 1968). Several studies in rats have demonstrated that a low-Mn diet caused a reduction in serum cholesterol; however, all of these studies

Table 3. Effect of dietary Mn concentration on whole blood Mn and serum cholesterol concentrations of beef heifers and their offspring

\begin{tabular}{|c|c|c|c|c|}
\hline \multirow[b]{2}{*}{ Item $^{1}$} & \multicolumn{2}{|c|}{$\begin{array}{l}\text { Supplemental Mn, } \\
\mathrm{mg} / \mathrm{kg}\end{array}$} & \multirow[b]{2}{*}{ SEM } & \multirow[b]{2}{*}{$P$} \\
\hline & 0 & 50 & & \\
\hline \multicolumn{5}{|l|}{ Whole blood $\mathrm{Mn}, \mathrm{ng} / \mathrm{mL}$} \\
\hline Birth $^{3}$ & 24.04 & 35.03 & 2.45 & \\
\hline End of study ${ }^{4}$ & 31.24 & 26.13 & 0.94 & 0.01 \\
\hline Cows $^{5}$ & 20.17 & 22.14 & 2.01 & 0.51 \\
\hline Cow serum cholesterol, mg/dL ${ }^{5}$ & 291.18 & 290.68 & 16.02 & 0.98 \\
\hline \multicolumn{5}{|c|}{${ }^{1}$ Measurements based on pen means. } \\
\hline \multicolumn{5}{|c|}{${ }^{2}$ Time $\times$ treatment effect $(P<0.01)$} \\
\hline \multicolumn{5}{|c|}{${ }^{3}$ Samples taken within $24 \mathrm{~h}$ of birth. } \\
\hline${ }^{4}$ Samples taken on d 267 whe & calves & & & \\
\hline
\end{tabular}


Table 4. Performance of calves born to heifers fed varying concentrations of dietary Mn

\begin{tabular}{|c|c|c|c|c|}
\hline \multirow[b]{2}{*}{ Item } & \multicolumn{2}{|c|}{$\begin{array}{l}\text { Supplemental Mn, } \\
\mathrm{mg} / \mathrm{kg}\end{array}$} & \multirow[b]{2}{*}{ SEM } & \multirow[b]{2}{*}{$P$} \\
\hline & 0 & 50 & & \\
\hline Birth weight, ${ }^{1} \mathrm{~kg}$ & 32 & 39 & 1.75 & 0.02 \\
\hline $\mathrm{ADG}, \mathrm{kg}^{2,3}$ & 0.82 & 0.84 & 0.08 & 0.84 \\
\hline
\end{tabular}

${ }^{1}$ Weights taken within $24 \mathrm{~h}$ of birth.

${ }^{2}$ Final weights taken on d 267 of study when calves averaged 67 d of age.

${ }^{3} \mathrm{ADG}=$ Average daily gain.

fed diets that were severely deficient in Mn (Curran and Azarnoff, 1961; Kawano et al., 1987; Davis et al., 1990). In the present study, the control diet was probably not low enough in $\mathrm{Mn}$ to see the dramatic serum cholesterol response demonstrated in rats.

Whole-blood Mn concentrations in heifers, measured on d 267, did not differ among treatments (Table 3). Weiss and Socha (2005) recently reported no differences among treatments in whole-blood Mn concentrations of heifers fed either a control diet (43 mg of $\mathrm{Mn} / \mathrm{kg}$ of DM) or a control diet supplemented with $200 \mathrm{mg} / \mathrm{d}$ of additional Mn. Similarly, Bentley and Phillips (1951) reported no differences in whole-blood Mn concentrations of heifers fed diets containing 7 to 10 or $30 \mathrm{mg}$ of $\mathrm{Mn} / \mathrm{kg}$ of DM for as long as $3 \mathrm{yr}$. Conversely, pregnant ewes fed diets containing $8 \mathrm{mg}$ of $\mathrm{Mn} / \mathrm{kg}$ of $\mathrm{DM}$ were found to have lower whole-blood Mn concentrations than those fed $68 \mathrm{mg}$ of $\mathrm{Mn} / \mathrm{kg}$ of $\mathrm{DM}$, with measurements taken up until lambing (Hidiroglou et al., 1978). Previously, we reported that plasma Mn concentrations in heifers were not affected by dietary Mn concentrations (Hansen et al., 2006). It is apparent that a rigorous homeostatic mechanism for Mn exists in the body, as whole-blood Mn concentrations were not affected in the present study even after heifers were fed 2 different concentrations of Mn for $463 \mathrm{~d}$.

Calves born to control heifers weighed less at birth $(P=0.02)$ than calves born to heifers supplemented with $50 \mathrm{mg}$ of $\mathrm{Mn} / \mathrm{kg}$ of DM (Table 4). Similar findings have been observed by Bentley and Phillips (1951), who reported a trend for heifers fed a diet containing 7 to $10 \mathrm{mg}$ of $\mathrm{Mn} / \mathrm{kg}$ of $\mathrm{DM}$ to give birth to lighter calves than did heifers who were fed diets containing $30 \mathrm{mg}$ of $\mathrm{Mn} / \mathrm{kg}$ of DM. Comparable results have been observed in other ruminants; kids born to goats fed a diet containing $1.9 \mathrm{mg}$ of $\mathrm{Mn} / \mathrm{kg}$ of $\mathrm{DM}$ were reported to weigh $17 \%$ less than kids born to goats fed a diet containing $90 \mathrm{mg}$ of Mn/kg of DM (Anke et al.,1973, as cited by Hidiroglou, 1979). In a study with limited animal numbers ( $\mathrm{n}=2$ or 3), Rojas et al. (1965) noted no differences in calf birth weights among cows fed dietary Mn concentrations of $15.8 \mathrm{mg}$ or $25.1 \mathrm{mg}$ of $\mathrm{Mn} / \mathrm{kg}$ of $\mathrm{DM}$, although marked skeletal deformities were observed in calves born to the low-Mn heifers.

Whole-blood Mn concentration of calves at birth was lower $(P=0.02)$ in calves born to control heifers than in calves born to supplemented heifers (Table 3). Similarly, calves born to dams fed $15.8 \mathrm{mg}$ of $\mathrm{Mn} / \mathrm{kg}$ of $\mathrm{DM}$ had lower whole-blood $\mathrm{Mn}$ concentrations than calves born to cows fed $25.1 \mathrm{mg}$ of $\mathrm{Mn} / \mathrm{kg}$ of DM (Rojas et al., 1965). In the present study, the reduced whole-blood Mn concentration of control calves at birth suggests that calves born to control heifers had a lower supply of Mn available during fetal development than calves born to supplemented heifers. It has been demonstrated that Mn can cross the placenta, although the actual mechanism by which this transfer occurs remains to be elucidated. Kontur and Fechter (1985) utilized ${ }^{54} \mathrm{Mn}$ to trace $\mathrm{Mn}$ transport across the placenta and into fetal tissues of rats when killed $2 \mathrm{~h}$ after an acute dose of ${ }^{54} \mathrm{MnCl}$. They found that the placenta accumulated a greater amount of ${ }^{54} \mathrm{Mn}$ than did other fetal tissues (1.5\% of the total dose), and total fetal tissues contained only $2.2 \%$ of the total maternal dose, indicating that Mn does cross the placenta but in very low amounts. In addition to fetal acquisition of $\mathrm{Mn}$ via the placenta, it has also been observed that storage of Mn in fetal tissues appears to be dependent on dietary intake of the dam (Rojas et al., 1965; Howes and Dyer, 1971).

In the blood sample taken on d 267 of the present study, when calves averaged $67 \mathrm{~d}$ of age, whole-blood Mn concentration was higher $(P=0.01)$ in control calves than in calves whose dams received supplemental $\mathrm{Mn}$ (Table 3). It is unclear why control calves had increased whole-blood Mn levels when compared with their supplemented counterparts at $67 \mathrm{~d}$ of age. It is possible that the lowered Mn status of the control calves caused increased absorption of dietary $\mathrm{Mn}$, and thus resulted in increased blood Mn levels. It has been shown that young animals have a greater capacity for absorption of Mn than adult animals, and that calves consuming a low-Mn diet had increased absorption of Mn compared with those receiving supplemental Mn (Howes and Dyer, 1971; Carter et al., 1974). Like most species, concentrations of Mn in cow's milk have been shown to be very low, ranging from 0.02 to $0.05 \mathrm{mg} / \mathrm{L}$ (Lonnerdal et al., 1981). There is no information on the absorptive capacity of calves for Mn from their dam's milk; however, the low concentrations of Mn present in cow's milk indicate that it is unlikely that this contributed a significant amount of $\mathrm{Mn}$ to the calves.

Calves born to control heifers tended to be $\operatorname{dwarfs}(P=$ 0.03 ) when compared with age-matched counterparts born to supplemented heifers (Table 5). At least one control calf seemed to have equilibrium problems, hold- 
Table 5. Observed signs of Mn deficiency in calves born to heifers fed $16.6 \mathrm{mg}$ of $\mathrm{Mn} / \mathrm{kg}$ of $\mathrm{DM}$

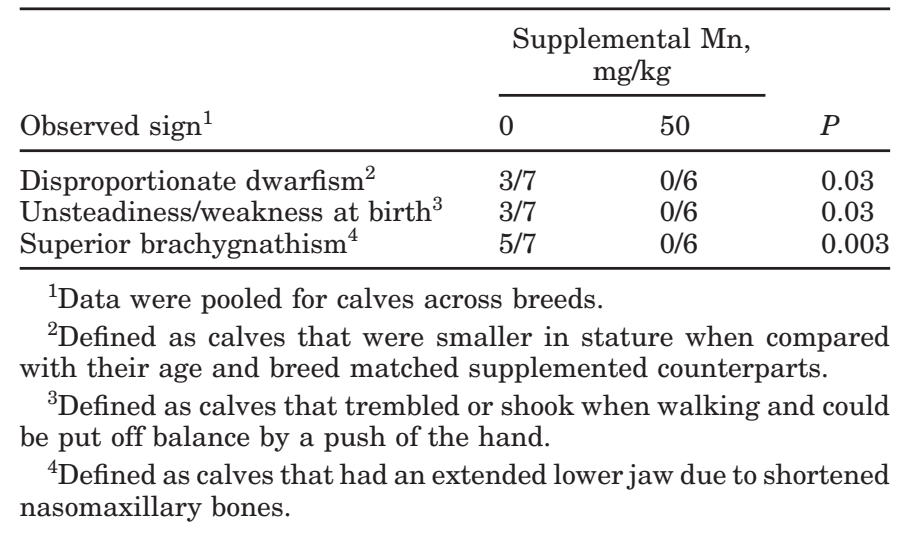

ing his head slightly tilted. A few of the calves born to control heifers were unsteady for several days after birth, moving stiffly and appearing to have swollen joints (Table 5). In agreement with the present study, young lambs exhibited poor movement and balance and increasing joint pain the longer they remained on a low$\mathrm{Mn}$ diet containing $0.8 \mathrm{mg}$ of $\mathrm{Mn} / \mathrm{kg}$ of $\mathrm{DM}$ (Lassiter and Morton, 1968). Lambs receiving a diet containing $29.9 \mathrm{mg}$ of $\mathrm{Mn} / \mathrm{kg}$ of DM did not appear to suffer from these problems.

Several clinical studies have observed a broad range of signs in young animals when Mn deficiency is suspected, from no observable changes to severe crippling and bending of the long bones (Rojas et al., 1965; Lassiter and Morton, 1968; Howes and Dyer, 1971). Although limited in animal numbers, Rojas et al. (1965) observed that calves born to cows fed diets containing $15.8 \mathrm{mg}$ of $\mathrm{Mn} / \mathrm{kg}$ of DM suffered from enlarged joints, weakness, and twisted legs. The calves born to Mndeficient dams had $13.9 \%$ shorter humeri than calves born to cows fed the control diet containing $25.1 \mathrm{mg}$ of $\mathrm{Mn} / \mathrm{kg}$ of DM. Humeri from the deficient calves required only $605 \mathrm{~kg}$ of vertical pressure to break, nearly half that required to break the humeri of a control calf (1, $186 \mathrm{~kg}$ of pressure; Rojas et al., 1965). Howes and Dyer (1971) also found that feeding a low-Mn diet (13 mg of $\mathrm{Mn} / \mathrm{kg}$ of $\mathrm{DM}$ ) to heifers resulted in calves that were weak and had trouble standing, whereas calves from heifers fed diets containing $21 \mathrm{mg}$ of $\mathrm{Mn} / \mathrm{kg}$ of $\mathrm{DM}$ appeared normal. Calves on the Howes and Dyer (1971) study did not exhibit the extreme malformation of bones observed by Rojas et al. (1965), but heifers were only fed the low-Mn diet for the last 3 mo of gestation.

In the present study, 5 of 7 calves born to control heifers exhibited some degree of superior brachygnathism-a shortening of the nasomaxillary bones, causing the lower jaw to appear extended (Figure 1). Severity of the ailment varied in each calf; in one calf the entire bottom row of teeth was exposed. None of the calves born to supplemented heifers exhibited any signs of superior brachygnathism $(P=0.003$; Table 5$)$. It is interesting to note that in rams the bone found to have the highest concentration of $\mathrm{Mn}$ is the lower jawbone, suggesting that decreased Mn availability may have caused the jaw problems observed in control calves (Odynets and Lysenko, 1966, as cited by Hidiroglou, 1980). Superior brachygnathism has not been a commonly reported sign of Mn deficiency in controlled studies; however, it has been found in several field observations in which a deficiency of Mn was suspected (Ribble et al., 1989; Valero et al., 1990; Staley et al., 1994). Several of these cases have been in Canada, where newborn calves exhibited a skeletal anomaly known as congenital joint laxity and dwarfism (CJLD). This disease is characterized by a generalized joint laxity, dwarfism, and on occasion, superior brachygnathism (Ribble et al., 1989). Observers noted that in many cases of CJLD births, pregnant cows had been wintered on grass or clover silage exclusively, and supplementation of cows with rolled barley or hay seemed to overcome any signs of CJLD (Ribble et al., 1989; Hidiroglou et al., 1990). Hidiroglou et al. (1990) reported a link between serum Mn concentrations and appearance of CJLD in calves. Hidiroglou et al. (1990) fed pregnant cows 1 of 3 feedstuffs (hay, red clover silage, or grass silage) and measured the frequency of CJLD in calves at birth for each group. Although all 3 feedstuffs contained similar levels of $\mathrm{Mn}(51,64$, and $63 \mathrm{mg}$ of $\mathrm{Mn} / \mathrm{kg}$ of $\mathrm{DM}$ for hay, red clover silage, and grass silage, respectively), $38 \%$ of calves born to red clover silage-fed cows, and $28 \%$ of the calves born to grass silage-fed cows were born with CJLD. None of the calves born to cows fed hay displayed any signs of CJLD. Serum Mn concentrations were lower in cows fed either of the silages than in cows fed hay.

Because whole-blood Mn concentrations in the present study were lower in control calves at birth, Mndependent enzymatic processes may have been limited in these calves compared with calves born to supplemented heifers. Manganese is required for the activation of glycosyltransferases, a group of enzymes involved in cartilage metabolism. Manganese deficiency in poultry has been shown to cause a reduction in mucopolysaccharide content of epiphyseal cartilage, which leads to skeletal deformities (Leach and Muenster, 1962). Ruminant studies have reported a direct correlation between dietary Mn concentration and Mn content of marrow-free bone (Rao, 1963; Howes and Dyer, 1971; Watson et al., 1973). The dwarfism, swollen joints, and superior brachygnathism observed in the control calves in the present study may indicate that low dietary $\mathrm{Mn}$ decreased glycosyltransferase activity. 

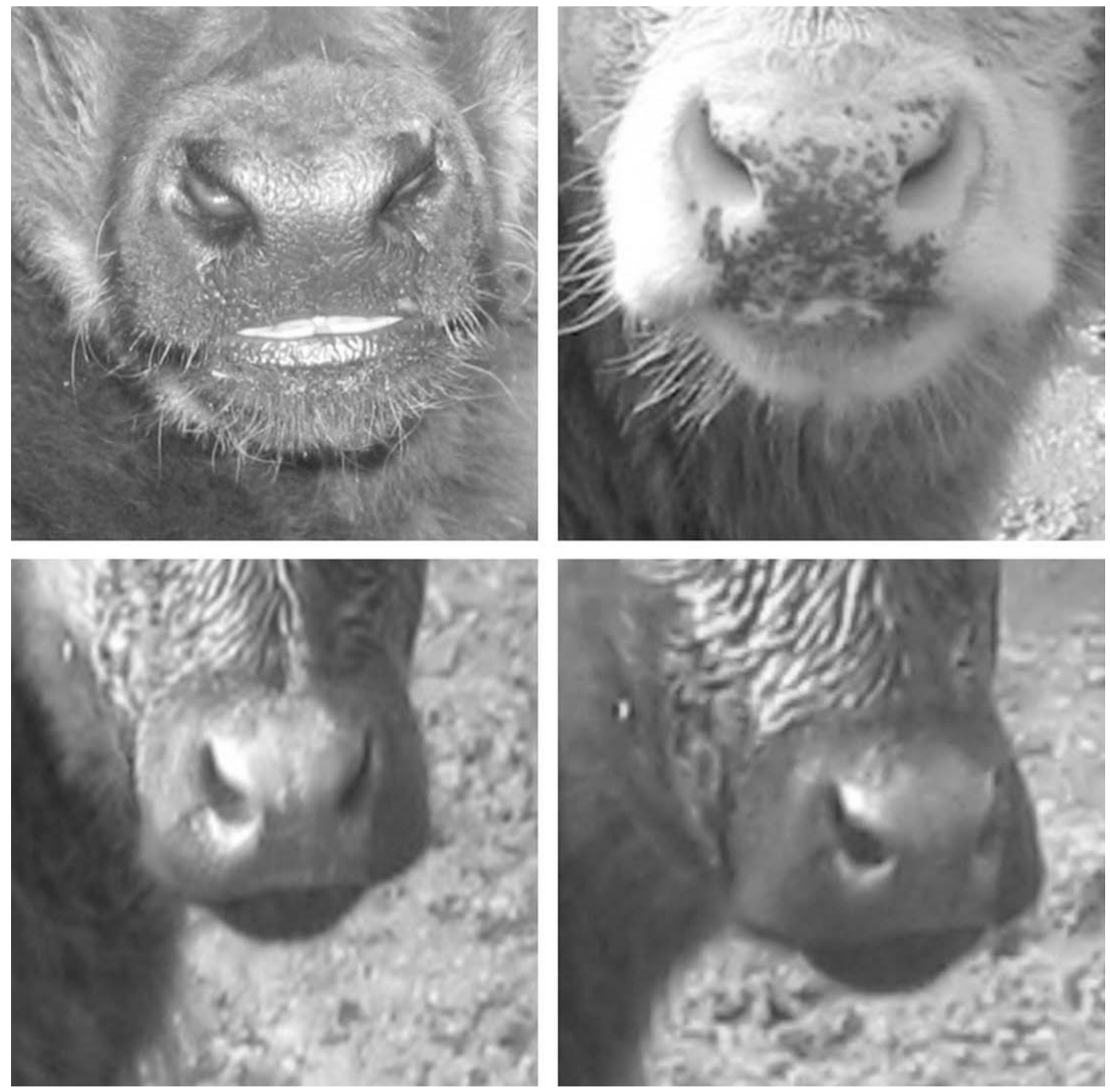

Figure 1. Several calves born to heifers receiving the low Mn diet exhibited varying degrees of superior brachygnathism (top row). For comparison purposes, 2 age-matched calves born to heifers fed supplemental Mn are shown in the bottom row. Due to difference in photography times, calves on the left side average $27 \mathrm{~d}$ of age, and calves on the right side average $83 \mathrm{~d}$ of age.

\section{CONCLUSIONS}

Results of the present study suggest that a diet containing $16.6 \mathrm{mg}$ of $\mathrm{Mn} / \mathrm{kg}$ of DM is insufficient for proper fetal development in gestating heifers. Calves born to heifers fed a diet containing $16.6 \mathrm{mg}$ of $\mathrm{Mn} / \mathrm{kg}$ of DM had lower blood Mn concentrations and exhibited varying degrees of dwarfism, superior brachygnathism, and weakness following birth. Addition of $50 \mathrm{mg}$ of $\mathrm{Mn} / \mathrm{kg}$ of DM to the control diet did not affect whole-blood Mn concentration of heifers but prevented signs of Mn deficiency in their calves. It is evident that control calves were at least marginally deficient in $\mathrm{Mn}$; however, no criteria for the evaluation of the Mn status of animals have been established. Although the most apparent signs of Mn deficiency in the present study were confined to the skeletal development of the calves, whole-blood Mn concentrations of calves at birth were consistently greater in those calves born to supplemented heifers. This suggests that whole-blood Mn may be an appropriate indicator of Mn status in the newborn calf. Based on these findings, it is apparent that, although a diet containing $16.6 \mathrm{mg}$ of $\mathrm{Mn} / \mathrm{kg}$ of $\mathrm{DM}$ was adequate for growth of heifers, it did not support proper fetal development. Clearly, the Mn requirement of the gestating heifer is higher than that of the growing heifer; however, the exact time frame in which this increased dependency occurs has yet to be elucidated.

\section{ACKNOWLEDGMENTS}

We would like to extend appreciation to G. Shaeffer, L. Legleiter, H. Stahlhut, J. Dickerson, J. Woodlief, 
and B. Matthews for their assistance in sampling and animal care.

\section{REFERENCES}

Bentley, O. G., and P. H. Phillips. 1951. The effect of low manganese rations upon dairy cattle. J. Dairy Sci. 34:396-403.

Carter, J. C., W. J. Miller, M. W. Neathery, R. P. Gentry, P. E. Stake, and D. M. Blackmon. 1974. Manganese metabolism with oral and intravenous ${ }^{54} \mathrm{Mn}$ in young calves as influenced by supplemental manganese. J. Anim. Sci. 38:1284-1290.

Curran, G. L., and D. L. Azarnoff. 1961. Effect of certain transition elements on cholesterol biosynthesis. Fed. Proc. 20:109-111.

Davis, C. D., D. M. Ney, and J. L. Greger. 1990. Manganese, iron and lipid interactions in rats. J. Nutr. 120:507-513.

Gengelbach, G. P., J. D. Ward, and J. W. Spears. 1994. Effect of dietary copper, iron, and molybdenum on growth and copper status of beef cows and calves. J. Anim. Sci. 72:2722-2727.

Hansen, S. L., J. W. Spears, C. S. Whisnant, and K. E. Lloyd. 2006. Growth, reproductive performance, and manganese status of beef heifers fed varying concentrations of manganese. J. Anim. Sci. (accepted)

Hidiroglou, M. 1979. Manganese in ruminant nutrition. Can. J. Anim. Sci. 59:217-236.

Hidiroglou, M. 1980. Zinc, copper and manganese deficiencies and the ruminant skeleton: A review. Can. J. Anim. Sci. 60:579-590.

Hidiroglou, M., S. K. Ho, M. Ivan, and D. A. Shearer. 1978. Manganese status of pasturing ewes, of pregnant ewes and doe rabbits on low manganese diets and of dairy cows with cystic ovaries. Can. J. Comp. Med. 42:100-107.

Hidiroglou, M., M. Ivan, M. K. Bryan, C. S. Ribble, E. D. Janzen, J. G. Proulx, and J. I. Elliot. 1990. Assessment of the role of manganese in congenital joint laxity and dwarfism in calves. Ann. Vet. Res. 21:281-284.

Howes, A. D., and I. A. Dyer. 1971. Diet and supplemental mineral effects on manganese metabolism in newborn calves. J. Anim. Sci. 32:141-145.

Kawano, J., D. M. Ney, C. L. Keen, and B. O. Schneeman. 1987. Altered high density lipoprotein composition in manganese-deficient Sprague-Dawley and Wistar rats. J. Nutr. 117:902-906.
Kontur, P. J., and L. D. Fechter. 1985. Brain manganese, catecholamine turnover, and the development of startle in rats prenatally exposed to manganese. Teratology 32:1-11.

Lassiter, J. W., and J. D. Morton. 1968. Effects of a low manganese diet on certain ovine characteristics. J. Anim. Sci. 27:776-779.

Leach, R. M., Jr., and E. D. Harris. 1997. Manganese. Pages 335356 in: Handbook of Nutritionally Essential Mineral Elements. B. L. O'Dell and R. A. Sunde, ed. Marcel Dekker Inc., New York, NY.

Leach, R. M. Jr., and A. Muenster. 1962. Studies on the role of manganese in bone formation. J. Nutr. 78:51-56.

Legleiter, L. R., J. W. Spears, and K. E. Lloyd. 2005. Influence of dietary manganese on performance, lipid metabolism, and carcass composition of growing and finishing steers. J. Anim. Sci. 83:2434-2439.

Lonnerdal, B., C. L. Keen, and L. S. Hurley. 1981. Iron, copper, zinc, and manganese in milk. Annu. Rev. Nutr. 1:149-174.

McDowell, L. R. 1992. Minerals in Animal and Human Nutrition. Academic Press, San Diego, CA.

National Research Council. 1996. Nutrient Requirements of Beef Cattle. 7th rev. ed. Natl. Acad. Sci., Washington, DC.

National Research Council. 2001. Nutrient Requirements of Dairy Cattle. 7th rev. ed. Natl. Acad. Sci., Washington, DC.

Rao, R. R. 1963. Manganese deficiency and reproductive phenomena in beef cattle and rats. MS Thesis, Washington State Univ., Pullman.

Ribble, C. S., E. D. Janzen, and J. G. Proulx. 1989. Congenital joint laxity and dwarfism: A feed-associated congenital anomaly of beef calves in Canada. Can. J. Vet. Med. 30:331-338.

Rojas, M. A., I. A. Dyer, and W. A. Cassatt. 1965. Manganese deficiency in the bovine. J. Anim. Sci. 24:664-667.

Staley, G. P., J. J. Van Der Lugt, G. Axsel, and A. H. Loock. 1994. Congenital skeletal malformations in Holstein calves associated with putative manganese deficiency. J. S. Afr. Vet. Assoc. 65:73-78.

Valero, G., M. R. Alley, L. M. Badcoe, B. W. Manktelow, M. Merrall, and G. S. Lawes. 1990. Chondrodystrophy in calves associated with manganese deficiency. N.Z. Vet. J. 38:161-167.

Watson, L. T., C. B. Ammerman, J. P. Feaster, and C. E. Roessler. 1973. Influence of manganese intake on metabolism of manganese and other minerals in sheep. J. Anim. Sci. 36:131-136.

Weiss, W. P., and M. T. Socha. 2005. Dietary manganese for dry and lactating Holstein cows. J. Dairy Sci. 88:2517-2523. 